\title{
Quantification of incubation, latent and infection periods of Phakopsora pachyrhizi in soybean, according to chronological time and degree-days
}

\author{
Anderson Luiz Durante Danelli ${ }^{1} \&$ Erlei Melo Reis ${ }^{2}$
}

\begin{abstract}
1,2Laboratório de Fitopatologia - Micologia, Faculdade de Agronomia e Medicina Veterinária, Universidade de Passo Fundo, 99001-970, Passo Fundo, RS, Brasil; ${ }^{1}$ Parte da Dissertação de mestrado do primeiro autor. Universidade Passo Fundo (2012); ${ }^{1}$ Bolsista Capes/Prosup/UPF; ${ }^{2}$ Endereço atual OR Melhoramento de Sementes Ltda, Passo Fundo, RS.
\end{abstract}

Autor para correspondência: Anderson Luiz Durante Danelli (andersondanelli@hotmail.com)

Data de chegada: 28/08/2013. Aceito para publicação em: 26/08/2015.

$10.1590 / 0100-5405 / 1920$

\section{ABSTRACT}

Danelli, A.L.D.; Reis, E.M. Quantification of incubation, latent and infection periods of Phakopsora pachyrhizi in soybean, according to chronological time and degree days. Summa Phytopathologica, v.42, n.1, p.11-17, 2016.

In experiments conducted in a growth chamber, the chronological time and the accumulated degree-days were determined for the duration of incubation, latent and infectious periods of Phakopsora pachyrhizi cultivars BRSGO 7560 and BRS 246 RR. Detached soybean leaflets were placed in gerboxtype acrylic boxes and inoculated with $20 \times 10^{3}$ uredospores $/ \mathrm{mL}$. The study was conducted at 12 -h photoperiod and temperatures of $10^{\circ} \mathrm{C}, 15^{\circ} \mathrm{C}$, $22^{\circ} \mathrm{C}, 25^{\circ} \mathrm{C}$ and $30^{\circ} \mathrm{C}$ for 30 days. Lesions and uredia $/ \mathrm{cm}^{2}$ were evaluated and the number of uredia per lesion was quantified after the beginning of sporulation. The sporulation potential was also quantified for cultivars BRSGO 7560 and BRS 246 RR. The steps of the infection process can be quantified based on both the chronological time and the accumulated heat. The cultivar BRSGO 7560 produced $4,012.8$ spores $/ \mathrm{cm}^{2}$ and BRS 246 RR, 7,348.4 uredospores $/ \mathrm{cm}^{2}$. The largest number of uredia was produced at $25^{\circ} \mathrm{C}$ in both cultivars; however, BRS $246 \mathrm{RR}$ presented $372.7 \mathrm{uredia} / \mathrm{cm}^{2}$ and BRSGO $7560,231.6$ uredia $/ \mathrm{cm}^{2}$. At $10^{\circ} \mathrm{C}$ and $30^{\circ} \mathrm{C}$, leaf infection did not occur in both cultivars.

Keywords: Glycine max, temperature, Asian soybean rust

\section{RESUMO}

Danelli, A.L.D.; Reis, E.M. Quantificação dos períodos de incubação, latente e infeccioso de Phakopsora pachyrhizi, em soja, por tempo cronológico e por graus-dia. Summa Phytopathologica, v.42, n.1, p.11-17, 2016.

Em experimentos conduzidos em câmara de crescimento determinou-se o tempo cronológico e os graus-dias acumulados para a duração dos períodos de incubação, latente e infeccioso de Phakopsora pachyrhizi nas cultivares BRSGO 7560 e BRS 246 RR. Folíolos de soja destacados foram acondicionados em caixas de acrílico tipo gerbox e inoculados com $20 \times 10^{3}$ uredosporos $/ \mathrm{mL}$. $\mathrm{O}$ trabalho foi conduzido com fotoperíodo de 12 horas e nas temperaturas de $10^{\circ} \mathrm{C}, 15^{\circ} \mathrm{C}, 22^{\circ} \mathrm{C}, 25^{\circ} \mathrm{C}$ e $30^{\circ} \mathrm{C}$ por 30 dias. Foram avaliadas lesões e urédias/ $\mathrm{cm}^{2}$ e o número de urédias por lesão quantificados após o início da esporulação.
Também foi quantificado o potencial de esporulação nos cultivares BRSGO 7560 e BRS 246 RR. As fases do processo de infecção podem ser quantificadas tanto pelo tempo cronológico como pelo calor acumulado. A cultivar BRSGO 7560 produziu 4.012,8 esporos $/ \mathrm{cm}^{2}$ e a BRS $246 \mathrm{RR} 7.348,4$ uredosporos $/ \mathrm{cm}^{2}$. $\mathrm{O}$ maior número de urédias foi produzido na temperatura de $25^{\circ} \mathrm{C}$ em ambas as cultivar, entretanto, a BRS 246 RR apresentou 372,7 urédias $/ \mathrm{cm}^{2}$ e a BRSGO $7560,231,6$ urédias $/ \mathrm{cm}^{2}$. Nas temperaturas de $10^{\circ} \mathrm{C}$ e $30^{\circ} \mathrm{C}$ não ocorreu infecção foliar em ambas as cultivares.

Palavras-chave: Glycine max, temperatura, ferrugem asiática

Asian soybean rust (ASR) is caused by Phakopsora pachyrhizi Syd. $\&$ P. Syd. This disease has led to yield losses in many grain-producing regions; in the Planalto Region of Rio Grande do Sul, in Southern Brazil, losses can be as high as $48 \%$ (24).

The first report of ASR in South America was in 2001, causing damage to soybean crop in Paraguay and Brazil (33).

The main control strategy for ASR is fungicide application on the leaves. In resistant cultivars, the pathogen cannot fully develop, resulting in decreased number of lesions, larger uredinium number/ lesion, decreased uredospore production and increased latent and infectious periods. These mechanisms result in reduced pathogen population by decreasing the amount of inoculum and consequently the disease intensity $(3,10)$.

Living organisms respond to stimuli that are environmental signals, such as water, temperature, and light (34). The growth and development of plant pathogens and their hosts generally respond to the temperature of their environment (35). The thermal time can be useful in modeling and evaluating the development of many pathogens that are important for agriculture (13).

The temperature acts as a catalyst, accelerating or slowing the development of the biological life cycle of the fungus, and interfering with uredospore development and germination (11), apressorium formation, uredinium development and sporulation (19), and teliospore formation and germination (25). 
For $P$. pachyrhizi, the infectious process is halted below $9^{\circ} \mathrm{C}$ and above $29^{\circ} \mathrm{C}$ (19). Alves et al. (2) reported the thermal limits of $9.6^{\circ} \mathrm{C}$ and $30^{\circ} \mathrm{C}$. Caldwell et al. (6) also studied the effect of temperature on the infectious process and did not find disease development at $15^{\circ} \mathrm{C}$ and $30^{\circ} \mathrm{C}$. Bonde et al. (4) studied the effect of temperature on uredospore germination, germ tube development and lesion density $/ \mathrm{cm}^{2}$, and reported thermal limits ranging from $10.4^{\circ} \mathrm{C}$ to $29.6^{\circ} \mathrm{C}$.

A large number of microorganisms have the ability to maintain their body temperature constant and are classified as endothermic; others do not demonstrate this ability and are known as exothermic (31). So far, this principle has been little explored in plant pathology. Fungi have their body temperature regulated by the environmental heat, which determines the duration of their life cycle and phase shift $(14,27)$.

One of the first studies using degree-days to measure the latent period was reported in 1983 for apple (Malus spp. (Borkh.)) and Venturia inaequalis Cooke. pathosystem by Tomerlin \& Jones (30). Scherm \& Van Bruggen (26) studied the effect of temperature, measured by degree-days, on the latent period of Bremia lactucae Rengel. Sun \& Yang (29) studied the influence of different light intensities quantified by degree-days on apothecium production of Sclerotinia sclerotiorum (Lib.) de Bary. Alves \& Fernandes (1) studied the influence of temperature and relative humidity on the sporulation of Magnaporthe grisea (Hebert) Barr. in wheat, showing that the conidium formation rate was related to the accumulative degree-days. Zearfoss et al. (35) developed a model based on degree-days to measure the latent period of Stagonospora nodorum (Berk) in winter wheat.

A warning model for ASR based on accumulated heat was developed by Reis et al. (23). The accumulated growing degree-days were calculated from the day of rust occurrence ( $1 \%$ leaflet incidence) in the current season up to the new occurrence in the next growing season. A thermal constant of $890^{\circ} \mathrm{C}$ was determined in a five-year experiment.

The hypothesis is that the subphases of the infection process can be measured based on accumulated degree-days.

This study aimed to determine incubation, latent and infectious periods for cultivars showing different reactions to ASR, using chronological time, expressed as days, and heat units, expressed as accumulated degree-days (ADD).

\section{MATERIAL AND METHODS}

The experiment was conducted in the Laboratory of Plant Pathology, University of Passo Fundo-UPF, Passo Fundo/RS. The ASR inoculum came from infected soybean plants collected in the UPF experimental field and kept, by frequent inoculation, in potted-soybean plants grown in a greenhouse at $25^{\circ} \mathrm{C}$ and $12-\mathrm{h}$ photoperiod.

Soybean cultivars BRSGO 7560, resistant to rust, 7.5 maturation group, and BRS 246 RR, susceptible, 7.2 maturation group, were used in this study.

Throughout this experiment, detached soybean leaflets were used (9). Healthy soybean trifoliate leaves were placed in acrylic boxes (11 x $11 \times 3.5 \mathrm{~cm}$ high) containing, at the bottom, nylon foam, $0.5 \mathrm{~cm}$ thick, and covered with an aluminum foil. Using a pair of tweezers, a hole was made in the aluminum foil and nylon foam to introduce the leaf petiole. Each box was supplemented with $20 \mathrm{ml}$ nutrient solution containing macro and micro nutrients and vitamin (20). The containers were kept in a growth chamber at $25^{\circ} \mathrm{C}$ and 12 -h photoperiod until complete petiole rooting.

For inoculation, leaves with abundant $P$. pachyrhizi sporulation were introduced in a plastic bottle containing $200 \mathrm{~mL}$ water and a drop of Tween 20/L water, and the suspension was stirred to remove the spores. Then, the spores were counted in a scanning microscope slide containing one drop of known volume. The spore suspension concentration was adjusted to a minimum of $20 \times 10^{3}$ uredospores/ $\mathrm{mL}(3)$ and the leaves were inoculated with a plastic manual sprayer.

After inoculation, the boxes were placed in a BOD-type incubator (biological oxygen demand), remaining in the dark for 8 hours for spore germination and leaf penetration. As the time elapsed, the boxes were transferred to a climatic chamber, 12-h photoperiod (supplied by eight white 40-Watts fluorescent light bulbs at $30 \mathrm{~cm}$ above the boxes), and supplemented with the nutrient solution at every three days.

Five constant temperatures, $10^{\circ} \mathrm{C}, 15^{\circ} \mathrm{C}, 22^{\circ} \mathrm{C}, 25^{\circ} \mathrm{C}$ and $30^{\circ} \mathrm{C}$, were tested. The evaluations were daily performed under a stereomicroscope (Zeiss $40 \mathrm{x}$ ), observing the development of domes (closed uredia) and the beginning of sporulation (open uredia with visible spores). Evaluations were made at 5, 10, 15, 20, 25 and 30 days after sporulation had begun. For each replicate, $1.0 \mathrm{~cm}$-diameter circles were marked with a stopper punch on the two leaf halves, one on the right side and the other one on the left side, totaling six assessed sites per leaf, where the lesions and uredinium number $/ \mathrm{cm}^{2}$ were counted. Data were expressed as lesion number $/ \mathrm{cm}^{2}$ and uredinium number/lesion.

Additional leaf discs, $1.0 \mathrm{~cm}$ diameter, at seven-day intervals, were transferred to test tubes with $10 \mathrm{~mL}$ distilled water and one drop of Tween $20 / \mathrm{L}$ water. A $0.01-\mathrm{mL}$ aliquot was taken with a micropipette and three drops were deposited on a microscope slide. Spore counting was performed by scanning the drops under a microscope. Data were expressed as uredospores $/ \mathrm{cm}^{2}$.

Degree-days (DD) were calculated according to the method of Villa Nova et al. (32), in which: DD = (MT - LTT), where: $M T=$ mean daily temperature and LTT $=$ lower threshold temperature. Similarly, ADD (accumulated degree-days) $=\sum \mathrm{DD}$ (degree-days) along 30 days. The LTT was taken from the study of Carlini (7), where basal, optimum and maximum temperatures for spore germination and germ tube growth of P. pachyrhizi uredospore were determined. In the experiments of Carlini, a temperature range at degree intervals from $5^{\circ} \mathrm{C}$ to $36^{\circ} \mathrm{C}$ and exposure times of $3,6,12$ and $24 \mathrm{~h}$ were tested. The considered basal temperature was $6^{\circ} \mathrm{C}$, optimal temperature $21^{\circ} \mathrm{C}$, and upper threshold $35^{\circ} \mathrm{C}$.

The latent period was considered the period from spore deposition on the leaf surface to the appearance of the first uredospores in the open uredia. The infectious period was considered the period from the end of the latent period to the final 30 days of the experiment, pre-determined to avoid leaf senescence.

The experiments were repeated twice.

The study was conducted in a completely randomized block design with five replicates for each temperature, in a 2 x 5 factorial arrangement (soybean cultivars and temperatures). Data were subjected to analysis of variance (ANOVA) and means compared according to Tukey's test. The equations expressed in each graph were used for regression, determining the Pearson's correlation coefficient among spores, lesions, uredia, and uredinium number/lesion.

\section{RESULTS}

Analysis of variance showed that the factor cultivar was significant only for uredia $(p=0.005)$, while the factor temperature showed significance for lesions $(p<0.001)$; however, for all tested variables, spores $(p=0.04)$, lesions $(\mathrm{p}=0.0138)$, uredia $(p=0.005)$, and uredinium number/lesion $(p=0.004)$, there was a significant interaction between temperature and cultivar (Table 1). 
Table 1. Mean squares (MS) and their significance $(p)$ according to $\mathrm{F}$ test for the studied sources of variation in the quantification of spores (no./ $\mathrm{cm}^{2}$ ), lesions (no./ $\mathrm{cm}^{2}$ ), uredia (no./ $/ \mathrm{cm}^{2}$ ) and uredia (no./lesion) of Asian soybean rust. UPF, Passo Fundo, RS, 2015

\begin{tabular}{|c|c|c|c|c|c|c|c|c|c|c|c|c|}
\hline \multirow{2}{*}{ Factor } & \multicolumn{3}{|c|}{ Spore $\left(\right.$ no. $\left./ \mathrm{cm}^{2}\right)$} & \multicolumn{3}{|c|}{ Lesion $\left(\mathbf{n o .} / \mathrm{cm}^{2}\right)$} & \multicolumn{3}{|c|}{ Uredia $($ no./cm²) } & \multicolumn{3}{|c|}{ Uredia (no./lesion) } \\
\hline & MS & $\mathbf{F}$ & $p$ & MS & $\mathbf{F}$ & $p$ & MS & $\mathbf{F}$ & $p$ & MS & $\mathbf{F}$ & $\mathbf{p}$ \\
\hline Cultivar & 1737001.3 & 2.4 & $0.06^{\mathrm{ns}}$ & 6.75362 & 0.0486 & $>0.050^{\mathrm{ns}}$ & 3430.4 & 4.4 & $0.005^{* *}$ & 16.2 & 2.2 & $0.08^{\text {ns }}$ \\
\hline Temperature & 475275.5 & 0.6 & $>0.05^{\mathrm{ns}}$ & 1660.86283 & 11.9474 & $<0.001 * *$ & 205.7 & 0.2 & $>0.05^{\text {ns }}$ & 6.8 & 0.9 & $>0.05^{\mathrm{ns}}$ \\
\hline Interaction & 1925930.9 & 2.7 & $0.04 *$ & 8.30594 & 0.0597 & $0.0138 *$ & 3412.4 & 4.4 & $0.005^{* *}$ & 32.7 & 4.4 & $0.004 * *$ \\
\hline
\end{tabular}

**: Significant at $1 \%$ probability *: Significant at $5 \%$ probability: ${ }^{\text {ns }}$ not significant

Table 2. Mean squares (MS) and significance ( $p$ ) according to $\mathrm{F}$ test for the studied and quantified causes of variation related to incubation, latent and infectious periods based on accumulated degree-days (ADD) and chronological time (CT) of Asian soybean rust. UPF, Passo Fundo, RS, 2015

\begin{tabular}{|c|c|c|c|c|c|c|c|c|c|}
\hline \multirow{2}{*}{ Factor } & \multicolumn{3}{|c|}{ Incubation period ADD } & \multicolumn{3}{|c|}{ Latent period ADD } & \multicolumn{3}{|c|}{ Infectious period ADD } \\
\hline & MS & $\mathbf{F}$ & $p$ & MS & $\mathbf{F}$ & $p$ & MS & $\mathbf{F}$ & $p$ \\
\hline Cultivar & 36205.1 & 296.8 & $<0.001 * *$ & 49928.5 & 313.9 & $<0.001 * *$ & 187695.7 & 1206.6 & $<0.001^{* *}$ \\
\hline Interaction & 23459.5 & 192.9 & $<0.001 * *$ & 38057.9 & 239.3 & $<0.001 * *$ & 133932.3 & 860.9 & $<0.001^{* *}$ \\
\hline Factor & \multicolumn{3}{|c|}{ Incubation period CT } & \multicolumn{3}{|c|}{ Latent period CT } & \multicolumn{3}{|c|}{ Infectious period CT } \\
\hline Temperature & 5.8 & 4.8 & $0.03 *$ & 4.1 & 2.9 & $0.0912^{\mathrm{ns}}$ & 4.1 & 2.3 & $0.09^{\text {ns }}$ \\
\hline Interaction & 200.7 & 166.4 & $<0.001 * *$ & 298.6 & 221.6 & $<0.001 * *$ & 409.8 & 305.3 & $<0.001 * *$ \\
\hline
\end{tabular}

**: Significant at $1 \%$ probability $*$ : Significant at $5 \%$ probability: ${ }^{\text {ns }}$ not significant.

Considering the analysis of variance for incubation, latency and infectious periods quantified according to ADD and chronological time, the factor cultivar was significant for all periods. The temperature was only significant for the incubation period quantified according to the chronological time (Table 2). The interaction between cultivars and temperature was significant $(\mathrm{p}<0.001)$ for all periods, when quantified according to either ADD or chronological time (Table 2).

At $22^{\circ} \mathrm{C}$, the number of produced spores differed between cultivars: BRSGO 7560 showed the smallest number, 2,500.2/ $\mathrm{cm}^{2}$, and BRS $246 \mathrm{RR}$, the largest number, $8,456.3 / \mathrm{cm}^{2}$. BRSGO 7560 produced the smallest spore number/ $\mathrm{cm}^{2}, 4,012.8$, and BRS $246 \mathrm{RR}$, the largest number, $7,348.4 / \mathrm{cm}^{2}$. The largest number of spores was produced at $22^{\circ} \mathrm{C}$ for BRS $246 \mathrm{RR}$, and at $25^{\circ} \mathrm{C}$ for BRSGO 7560 (Figure 1A).

Regarding lesion $/ \mathrm{cm}^{2}$, the means did not differ among cultivars: on average, 23.8 lesions $/ \mathrm{cm}^{2}$ were counted for BRSGO 7560 and 24.5 lesions $/ \mathrm{cm}^{2}$ for BRS $246 \mathrm{RR}$. At $15^{\circ} \mathrm{C}$, the lowest means were recorded, 2.8 lesions $/ \mathrm{cm}^{2}$, and at $22^{\circ} \mathrm{C}$ and $25^{\circ} \mathrm{C}$, the highest means were obtained, 24.9 and 25.7 lesions $/ \mathrm{cm}^{2}$ (Figure $1 \mathrm{~B}$ ).

BRSGO 7560 produced the smallest number of uredia and BRS $246 \mathrm{RR}$, the largest number. At $15^{\circ} \mathrm{C}, 22^{\circ} \mathrm{C}$ and $25^{\circ} \mathrm{C}$, BRSGO 7560 produced $81.5,168.8$ and 231.6 uredia $/ \mathrm{cm}^{2}$, respectively, while BRS 246 RR produced $141.5,291.5$ and $372.7 \mathrm{uredia} / \mathrm{cm}^{2}$, respectively (Figure 1C).

The cultivar BRSGO 7560 showed the smallest uredinium number/ lesion. At $15^{\circ} \mathrm{C}$, BRSGO 7560 showed 3.6 uredia/lesion, while BRS $246 \mathrm{RR}$ presented 6.7 uredia/lesion. At $22^{\circ} \mathrm{C}$, BRSGO 7560 produced 6.8 uredia/lesion and BRS $246 \mathrm{RR}$ showed 11.5 uredia/lesion. At $25^{\circ} \mathrm{C}$, BRSGO 7560 had 9.5 uredia/lesion and BRS 246 RR formed 13.7 uredia/lesion. The largest uredinium number/lesion was found at $25^{\circ} \mathrm{C}$ (Figure 1D).

The effect of temperature on the incubation period, assessed based on DD, for both cultivars, indicated that the lowest ADD was found at $15^{\circ} \mathrm{C}$ and the highest one at $25^{\circ} \mathrm{C}$ (Figure $2 \mathrm{~A}$ ). The effect of temperature on the incubation period, measured according to the chronological time, indicated that the smallest number of days was found at $25^{\circ} \mathrm{C}$, and the largest number at $15^{\circ} \mathrm{C}$ for both cultivars (Figure 2B).

Considering the duration of the latent period assessed based on the ADD, the highest ADD values were found at $25^{\circ} \mathrm{C}$, and the lowest values at $15^{\circ} \mathrm{C}$ (Figure $2 \mathrm{C}$ ). When analyzed according to the chronological time, the largest number of days was observed at $15^{\circ} \mathrm{C}$ and the smallest one at $25^{\circ} \mathrm{C}$ (Figure 2D).

Regarding the infectious period according to ADD, the highest values were found at $25^{\circ} \mathrm{C}$ for both cultivars and the lowest values were found at $15^{\circ} \mathrm{C}$ (Figure 2E). In the chronological analysis for the infectious period, the largest number of days was observed at $25^{\circ} \mathrm{C}$, and the smallest one at $15^{\circ} \mathrm{C}$ (Figure $2 \mathrm{~F}$ ).

In the evaluation of incubation, latent and infectious periods, as temperature was reduced $\left(15^{\circ} \mathrm{C}\right), \mathrm{ADD}$ also decreased, thus taking longer for the first symptoms to appear. At $22^{\circ} \mathrm{C}$ and $25^{\circ} \mathrm{C}$, the ADD was higher, reducing the number of days for the onset of spores.

The latent period at the temperatures of $15^{\circ} \mathrm{C}, 22^{\circ} \mathrm{C}$ and $25^{\circ} \mathrm{C}$ was $17,10.2$ and 8 days, respectively, for BRSGO 7560, and 19, 9.3 and 8 days, respectively, for BRS $246 \mathrm{RR}$. The longest latent periods were found at the temperature of $15^{\circ} \mathrm{C}$ and the shortest ones at $22^{\circ} \mathrm{C}$ and $25^{\circ} \mathrm{C}$ (Figure 2D).

The infectious period at $15^{\circ} \mathrm{C}, 22^{\circ} \mathrm{C}$ and $25^{\circ} \mathrm{C}$ was $13,19.7$ and 22 days, respectively, for BRSGO 7560, and 11, 20.7 and 22 days, respectively, for BRS $246 \mathrm{RR}$. The longest latent periods were found at $22^{\circ} \mathrm{C}$ and $25^{\circ} \mathrm{C}$ and the shortest ones at $15^{\circ} \mathrm{C}$ (Figure $2 \mathrm{~F}$ ).

Correlation analysis showed a high degree of positive linearity between spores (no. $\left./ \mathrm{cm}^{2}\right)$ and lesions $\left(\right.$ no. $\left./ \mathrm{cm}^{2}\right)(\mathrm{r}=0.91 ; p=0.0034)$, spores $\left(\right.$ no. $\left./ \mathrm{cm}^{2}\right)$ and uredia $\left(\right.$ no. $\left./ \mathrm{cm}^{2}\right)(\mathrm{r}=0.94 ; p<0.0001)$, lesions (no./ 

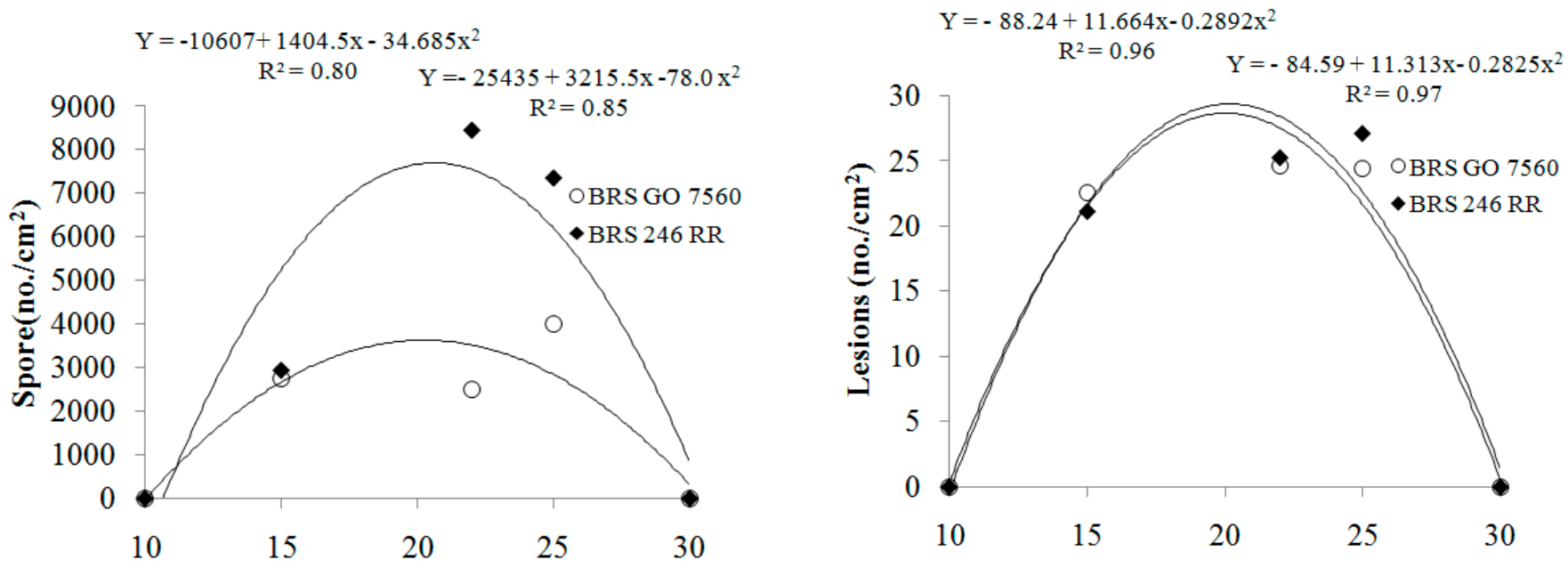

C

D
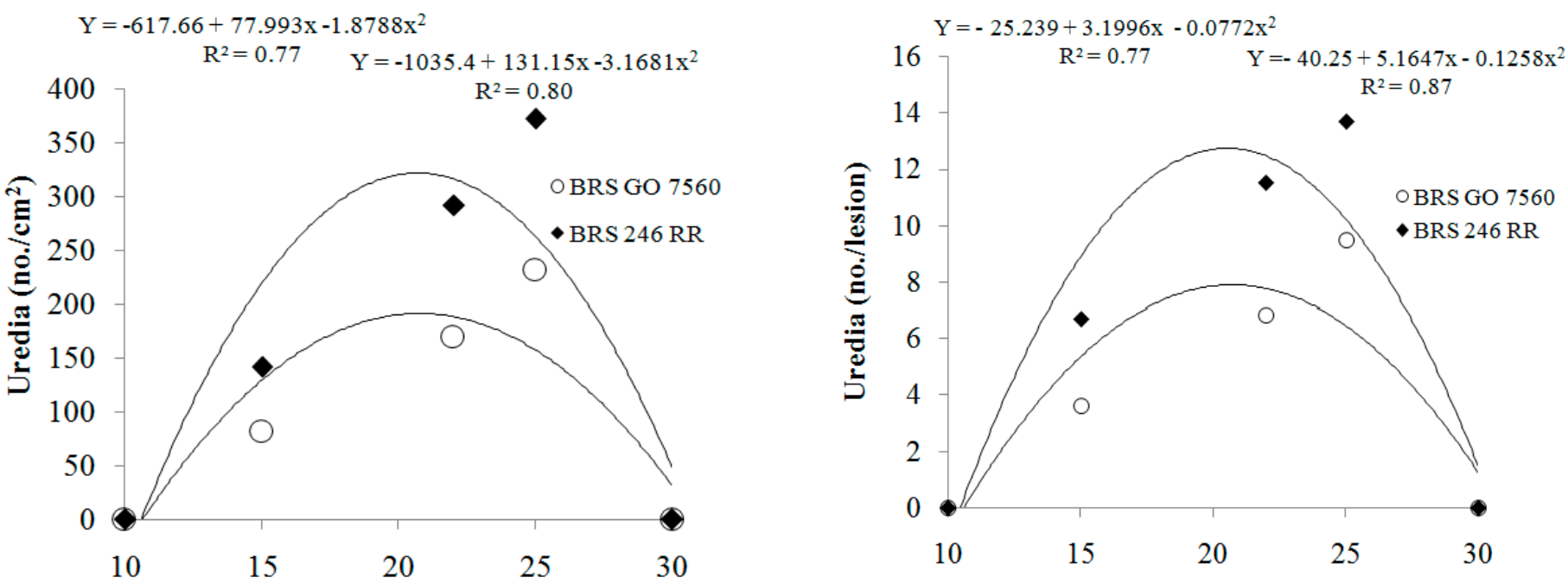

Temperature $\left({ }^{\circ} \mathrm{C}\right)$

Figure 1. Spores $\left(\right.$ no. $\left./ \mathrm{cm}^{2}\right)(\mathrm{A})$, lesions $\left(\right.$ no. $\left./ \mathrm{cm}^{2}\right)(\mathrm{B})$, uredia $\left(\right.$ no. $\left./ \mathrm{cm}^{2}\right)(\mathrm{C})$ and uredia (no./lesion) (D), produced by Phakopsora pachyrhizi inoculated in BRSGO 7560 and BRS 246 RR soybean cultivars at different temperatures. UPF, Passo Fundo, RS, 2015.

$\left.\mathrm{cm}^{2}\right)$ and uredia $\left(\right.$ no. $\left./ \mathrm{cm}^{2}\right)(\mathrm{r}=0.90 ; p<0.0001)$, and uredia $\left(\right.$ no. $\left./ \mathrm{cm}^{2}\right)$ and uredia (no./lesion) $(\mathrm{r}=0.82 ; p<0.0001)$. The lowest correlation coefficients were found for the relationship between lesions $\left(\mathrm{no} . / \mathrm{cm}^{2}\right)$ and uredia (no./lesion) $(\mathrm{r}=0.59 ; p<0.0001)$, and spores $\left(\mathrm{no.} / \mathrm{cm}^{2}\right)$ and uredia (no./lesion) $(\mathrm{r}=0.34 ; p<0.0145)$ (Table 3$)$. There was no foliar infection at $10^{\circ} \mathrm{C}$ and at $30^{\circ} \mathrm{C}$.

\section{DISCUSSION}

According to Souza et al. (28), the cultivar BRSGO 7560 carries a major gene that confers vertical resistance to soybean rust. At a high inoculum density, this cultivar can show susceptible lesions of tan color, which can be indicative of the lowest number of lesions found in this study. Another important aspect is that a resistance break can occur along the growing seasons due to the development of new races.

Comparing the cultivars BRS 246 RR and BRSGO 7560, regarding spore number $/ \mathrm{cm}^{2}$, uredinium number $/ \mathrm{cm}^{2}$, and uredinium number/ lesion, the statistical analysis showed differences between cultivars: BRS 246 RR showed the highest values, while BRSGO 7560 showed the lowest values.

Soybean lines with partial resistance have been identified and characterized based on the uredinium number/lesion (5). Our data for uredia/lesion are similar to those reported by Reis et al. (22), who found 14 uredia/lesion. In a study conducted by Azevedo et al. (3), the mean uredinium number $/ \mathrm{cm}^{2}$ ranged from 4.5 to 7.8 . Regarding the total number of produced spores, Melching et al. (17) reported sporulation values of different isolates similar to those found in our study.

Our results showed that the optimal temperature ranged between $22^{\circ} \mathrm{C}$ and $25^{\circ} \mathrm{C}$, with the largest number of spores, lesions, uredia, and uredia/lesion. At $10^{\circ} \mathrm{C}$ and $30^{\circ} \mathrm{C}$, there was no leaf infection; this is probably due to constant temperature, which does not occur in the field. The environmental conditions required for soybean rust infection have been well defined in two temperature/leaf wetness combination studies 
A

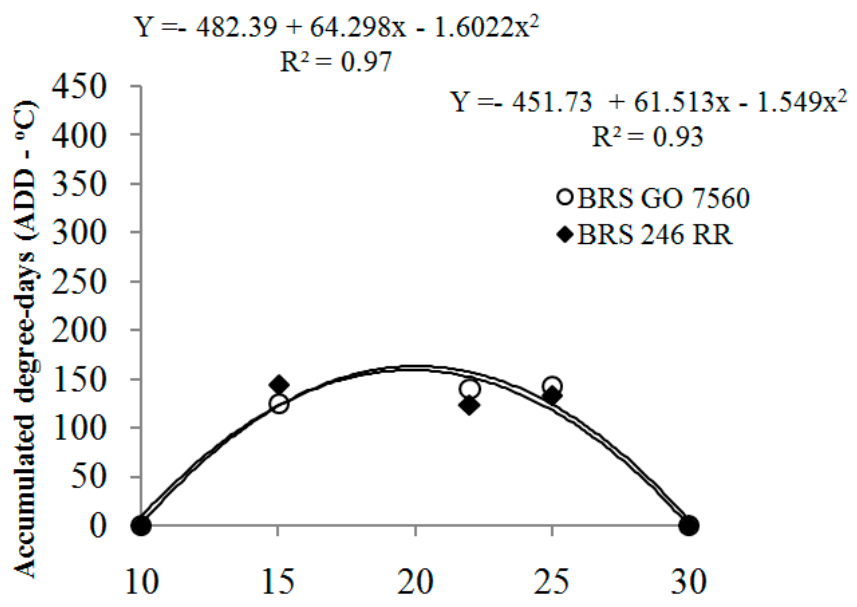

C

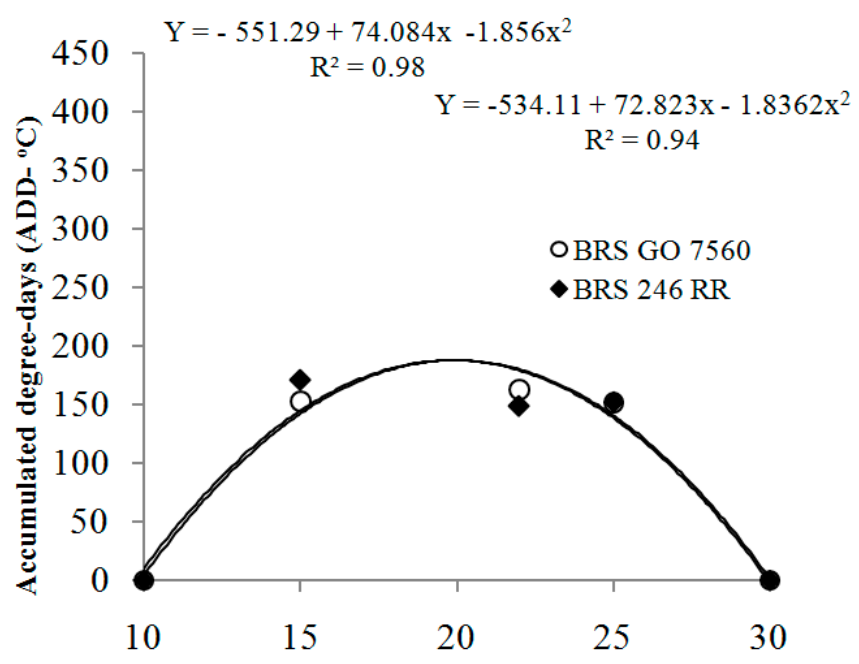

E

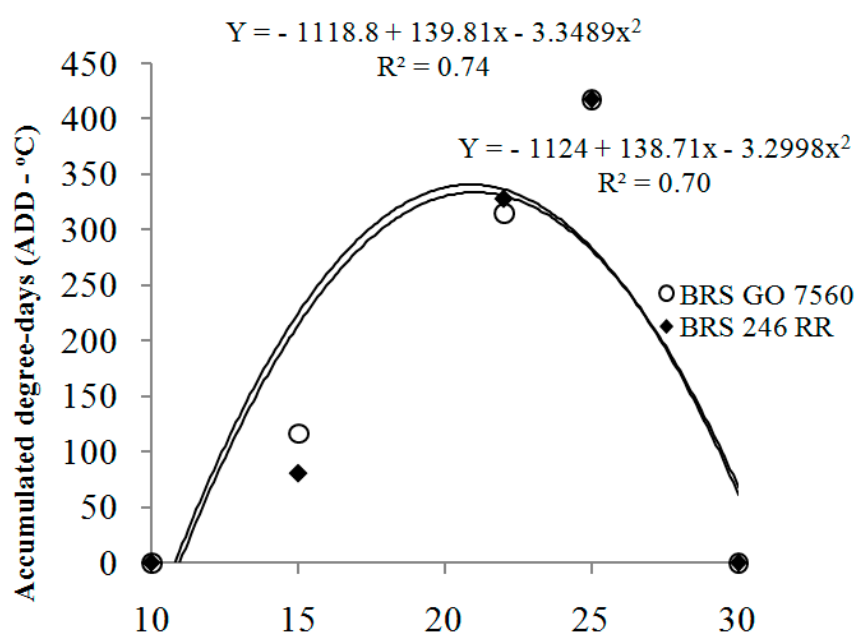

B

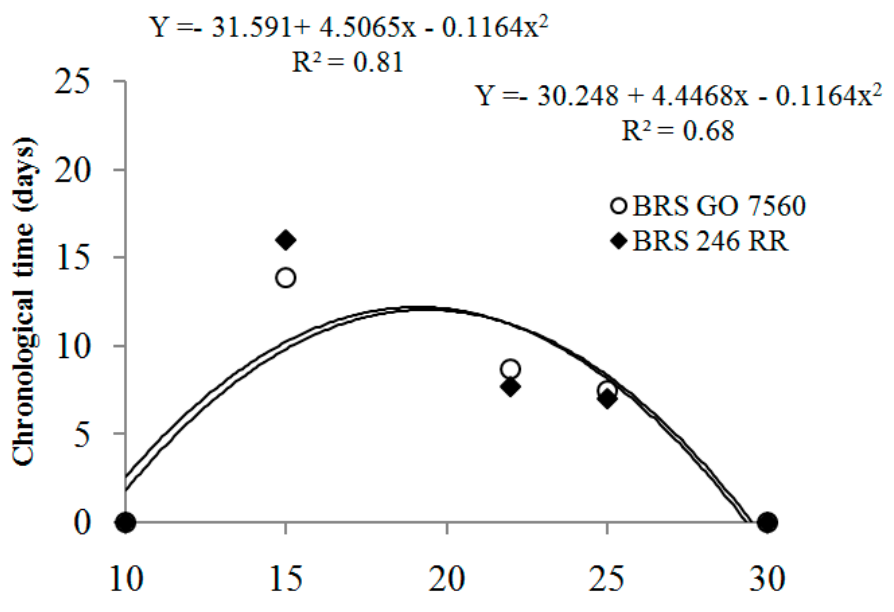

D

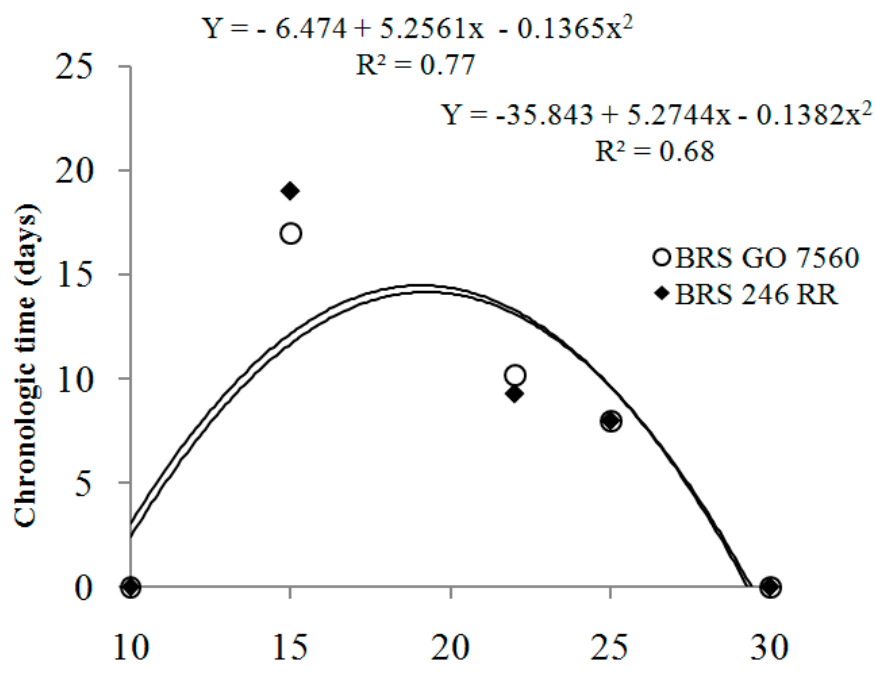

F

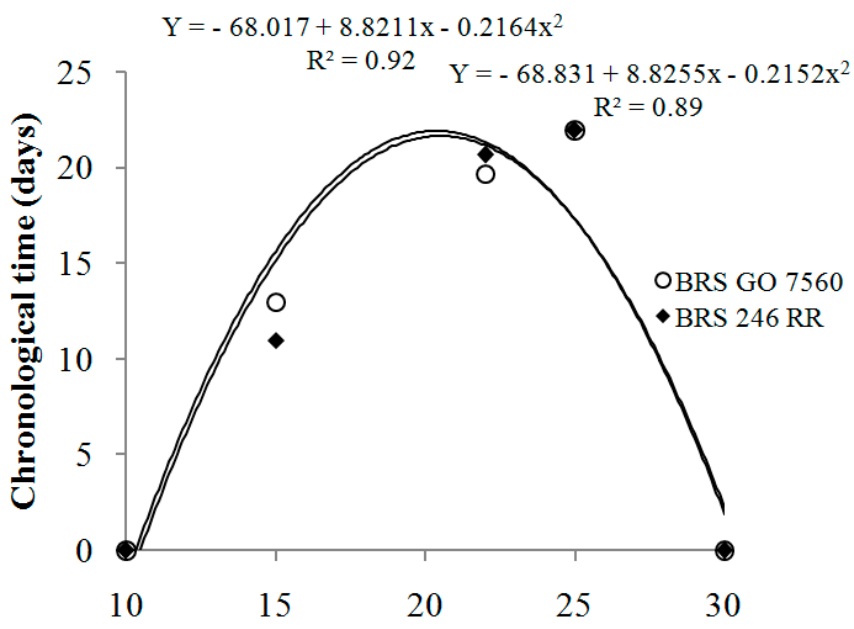

Temperature $\left({ }^{\circ} \mathrm{C}\right)$

Figure 2. Effect of temperature on incubation period (A), latent period (C) and infectious period (E) of Phakopsora pachyrhizi, rated based on accumulated degree-days (ADD - ${ }^{\circ} \mathrm{C}$ ), and effect of temperature on incubation period (B), latent period (D) and infectious period (F) (days) of Phakopsora pachyrhizi, rated based on chronological time (days) and inoculated in BRSGO 7560 and BRS 246 RR soybean cultivars. 
Table 3. Level of significance $(p)$ and correlation coefficients $\left(\mathrm{r}^{2}\right)$ of spores (no./ $\left.\mathrm{cm}^{2}\right)$, lesions (no./cm $\left.{ }^{2}\right)$, uredia (no./ $\left.\mathrm{cm}^{2}\right)$ and uredia (no./lesion) of Asian soybean rust. UPF, Passo Fundo, RS, 2015

\begin{tabular}{|c|c|c|c|c|}
\hline & Spores $\left(\right.$ no. $\left./ \mathrm{cm}^{2}\right)$ & Lesions (no./cm²) & Uredia $($ no./cm²) & Uredia (no./lesion) \\
\hline \multirow[t]{2}{*}{ Spores $\left(\mathrm{no} . / \mathrm{cm}^{2}\right)$} & 1.00000 & 0.912702 & $0.938397 \quad p<0.0001 * *$ & 0.344724 \\
\hline & & $p=0.0034 * *$ & & $p=0.0145 *$ \\
\hline \multirow[t]{2}{*}{ Lesions (no. $/ \mathrm{cm}^{2}$ ) } & & 1.00000 & 0.901299 & 0.588767 \\
\hline & & & $p<0.0001 * *$ & $p<0.0001^{* * *}$ \\
\hline \multirow[t]{2}{*}{ Uredia $\left(\mathrm{no} . / \mathrm{cm}^{2}\right)$} & & & 1.00000 & 0.817991 \\
\hline & & & & $p<0.0001 * *$ \\
\hline Uredia (no./lesion) & & & & 1.00000 \\
\hline
\end{tabular}

$(15,18)$. The optimal temperature for infection was $20^{\circ} \mathrm{C}-25^{\circ} \mathrm{C}$ and at least 6-8 hours of continuous leaf wetness.

The high degree of positive linearity found in the correlation analysis for spores (no. $\left./ \mathrm{cm}^{2}\right)$ and lesions $\left(\right.$ no. $\left./ \mathrm{cm}^{2}\right)$, spores (no. $\left./ \mathrm{cm}^{2}\right)$ and uredia $\left(\right.$ no. $\left./ \mathrm{cm}^{2}\right)$, uredia $\left(\right.$ no. $\left./ \mathrm{cm}^{2}\right)$ and uredia (no./ lesion) was expected, because when the number of lesions increase, the number of spores and uredia also increase.

Phakopsora pachyrhizi has a relatively short latent period, compared to other pathogens. Nevertheless, it varies with temperature, i.e., 9 to 14 days (11), 8 to 10 days (18) 9 days (3), 11 to 16 days (16), 8 to 9 days (8) 14 to 28 days (7), 9 to 12 days (12).

According to Trudgill (31), the duration of the life cycle and the change in phenological stages for ectothermics can be modeled by using degree-days or accumulated heat, i.e., it can be inferred that the annual cycle duration of the fungus is governed by the accumulated heat of the environment. The most relevant results of our study regarding the thermal time to describe the stages of the disease cycle were that, regardless of temperature, the ADD are the same for both latent and incubation periods.

Chronological variation was expected since it is influenced by temperature. Considering the infectious period alone, as there was an increase in temperature, the infectious period also increased. These results agree with those reported by Carlini (7), Lange et al. (12) and Reis et al. (23) when the phases and sub-phases of $P$. pachyrhizi in soybean were quantified by the use of degree-days or accumulated heat.

The study of weather effects, such as temperature, on the pathogen development phases (incubation period and latent infection) are important to model the epidemics and thus assist in the management of diseases $(21,23,29,35)$.

\section{ACKNOWLEDGMENTS}

We would like to thank "Coordenação de Aperfeiçoamento de Pessoal de Nível Superior-CAPES", the Program to Support Graduate Education in Private Institutions - PROSUP, and "Universidade de Passo Fundo-UPF", for the scholarships.

\section{REFERENCES}

1. Alves, K.J.P.; Fernandes, J.M.C. Influência da temperatura e da umidade relativa do ar na esporulação de Magnaporthe grisea em trigo. Fitopatologia Brasileira, Brasília, v.31, n.6, p.579-584, 2006.

2. Alves, S.A.M.; Furtado, G.Q.; Godoy, C.V.; Bergamin Filho, A. Influência da temperatura no período latente da ferrugem asiática da soja. Summa Phytopathologica, Botucatu, v.32, Suplemento, p. S71, 2006. (Resumo). 3. Azevedo, L.A.S.; Juliatti. F.C.; Barreto, M. Resistência de genótipos de soja à Phakopsora pachyrhizi. Summa Phytopathologica, Botucatu, v.33, n.3, p.252-257, 2007.

4. Bonde, M.R.; Berner, D.K.; Nester, S.E.; Frederick, R.D. Effects of temperature on urediniospore germination, germ tube growth, and initiation of infection in soybean by Phakopsora isolates. Phytopathology, St Paul, v.97, n.8, p.997-1003, 2007.

5. Bonde, M.R.; Nester, S.E.; Austin, C.N.; Stone, C.L.; Frederick, R.D.; Hartman, G.L.; Miles, M.R. Evaluation of virulence of Phakopsora pachyrhizi and P. meibomiae isolates. Plant Disease, St Paul, v.90, n.6, p.708-716, 2006.

6. Caldwell, P.M.; Nunkumar, A.; Pretorius, Z.A.; Fernandes, J.M.C. Development of Phakopsora pachyrhiziat different temperatures, relative humidities and leaf wetness duration. In: International Workshop on Plant Disease Epidemiology, 9., Landerneau, 2005. Proceedings. 2005. Bordeaux: Societé Francaise de Phytopathologie, 2005. Abstract C3.

7. Carlini, R.C. Germinação de uredosporos e período latente de Phakopsora pachyrhyzi determinado por tempo cronológico e unidades de calor. 2009. 63p. Dissertação (Mestrado em Agronomia). Programa de Pós-Graduação em Agronomia - Universidade de Passo Fundo, Passo Fundo.

8. Furtado, G.Q.; Alves, S.A.M.; Carneiro, L.C.; Godoy, C.V.; Massola Júnior, N.S. Influência do estádio fenológico e da idade dos trifólios de soja na infecção de Phakopsora pachyrhizi. Tropical Plant Pathology, Brasília, v.34, n.2, p.118-122, 2009.

9. Garcia, R.A.; Juliatti, F.C. Avaliação da resistência da soja a Sclerotinia sclerotiorum em diferentes estádios fenológicos e períodos de exposição ao inóculo. Tropical Plant Pathology, Brasília, v.37, n.3, p.196-203, 2012.

10. Kim, K.S.; Wang, T.C.; Yang, X.B. Simulation of apparent infection rate to predict severity of soybean rust using a fuzzy logic system. Phytopathology, St Paul, v.95, n.10, p.1122-1131, 2005.

11. Kochman, J.K. The effect of temperature on development of soybean rust (Phakopsora pachyrhizi). Australian Journal Agricultural Research, Clayton, v.30, n.2, p.273-277, 1979.

12. Lange, M.S.; Deuner, C.C.; Ghissi, V.C.; Beledelli, G.L.; Danelli, A.L.D.; Reis, E.M. Efeito da temperatura nas fases do ciclo biológico de Phakopsora pachyrhizi. Tropical Plant Pathology, Brasília, v.36, Suplemento, p.210, 2011. (Resumo).

13. Lovell, D.J.; Powers, S.J.; Welham, S.J.; Parker, S.R. A perspective on the measurement of time in plant disease epidemiology. Plant Pathology, St. Paul, v.53, p.705-712, 2004.

14. Machardy, W.E.; Gadoury, D.M. Forecasting the seasonal maturation of ascospores of Venturia inaequalis. Phytopathology, St. Paul, v.75, n.4, p.381-385, 1985.

15. Marchetti, M.A.; Melching, J.S.; Bromfield, K.R. The effects of temperature and dew period on germination and infection by urediospores of Phakopsora pachyrhizi. Phytopathology, St. Paul, v.66, n.4 , p.461-463, 1976.

16. Martins, J.A.S.; Juliatti, F.C.; Santos, V.A.; Polizel, A.C. Período latente e uso da análise de componentes principais para caracterizar a resistência parcial à ferrugem da soja. Summa Phytopathologica, Botucatu, v.33, n.4, p.364-371, 2007.

17. Melching, J.S.; Bromfield, K.R.; Kingsolver, C.H. Infection, colonization and uredospore production on Wayne soybean by four cultures of Phakopsora pachyrhizi. Phytopathology, St. Paul, v.69, n.12, p.1262-1265, 1979.

18. Melching, J.S.; Dowler, W.M.; Koogle, D.L.; Royer, M.H. Effect of plant and leaf age on susceptibility of soybean to soybean rust. Canadian Jour- 
nal of Plant Pathology, Ontario, v.10, n.1, p.30-35, 1988.

19. Melching, J.S.; Dowler, W.M.; Koogle, D.L.; Royer, M.H. Effect of duration, frequency, and temperature of leaf wetness period on soybean rust. Plant Disease, St. Paul, v.73, n.2, p.117-122, 1989.

20. Murashige, T.; Skoog, F. The revised médium for rapid growrh and bioassays with tobacco tissue cultures. Physiologia Plantarum, Copenhagen, v.15, n.3, p.473-497, 1962.

21. Paveley, N.D. Integrating septoria risk variables. In: Lucas JA, Bowyer P, Anderson HM (Eds) Septoria on Cereals: A Study of Pathosystems. CABI Publishing, Wallingford, UK, 1999. p. 230-250

22. Reis, E.M.; Reis, A.C.; Carmona, M.; Danelli, A.L.D. Ferrugem asiática Em: Reis E.M., Casa R.T. (Eds) Doenças da soja: etiologia, sintomalogia, diagnose e manejo integrado. Passo Fundo, Berthier, 2012a. p. 69-104

23. Reis, E.M.; Zoldan, S.; Brustolin, R.; Nicolini, F.; Yoiti Tsukahara, R.Y. Sistema de aviso da ocorrência da ferrugem da soja baseado em calor acumulado. In: VI Congresso Brasileiro de Soja: integração nacional e desenvolvimento sustentável, Resumos... Cuiabá: Embrapa, 2012b. p.148.

24. Reunião de Pesquisa da Soja da Região Sul, 39., 2012. Indicações Técnicas para a Cultura da Soja no Rio Grande do Sul e em Santa Catarina, safras 2012/2013 e 2013/2014. In: XXXIX Reunião de Pesquisa de Soja. Passo Fundo RS. Embrapa Trigo. 2012. 142p.

25. Saksirirat, W.; Hoppe, H.H. Teliospore germination of soybean rust fungus (Phakopsora pachyrhizi Syd.). Journal of Phytopathology, St. Paul, v.132, n. 4, p.339-342, 1991.

26. Scherm, H.; Van Bruggen, A.H.C. Effects of fluctuating temperatures on the latent period of lettuce downy mildew (Bremia lactucae). Phytopathology, St. Paul, v.84, n.8, p.853-859, 1994.

27. Shöffel, E.R.; Volpe, C.A. Relação da soma térmica efetiva e o crescimento da soja. Revista Brasileira de Agrometeorologia, Fortaleza, v.10, n.1, p.89-96, 2002.
28. Souza, P.I.M.; Toledo, J.F.F.; Moreira, C.T.; Farias Neto, A.; Da Silva, A.S.; Arantes, N.E.; Mello Filho, O.; Carneiro, G.E.S.; Monteiro, P.M.F.O.; Arias, C.A.A.; Kaster, M.; Oliveira, M.F.; Pípolo, A.E.; Brogin, R.L.; Nunes Júnior, J.; Abdelnoor, R.V.; Almeida, Á.M.R.; Meyer, M.C.; Andrade, P.J.M.; Carrão-Panizi, M.C.; Dias, W.P.; Moreira, U.V.J.; Neiva, L.C.S.; Nunes, M.R.; Seii, A.H., Silva, L.O.; Silva, N.S.; Teixeira, R.N.; Soares, R.M.; Toledo, R.M.C.P.; Vieira, N.E. Variedade de soja resistente à ferrugem (BRS GO 7560): posicionamento da nova tecnologia. In: Reunião do consórcio antiferrugem safra 2008-2009, Resumos... Londrina: Embrapa, 2009. p. 89-92.

29. Sun, P.; Yang, X.B. Light, temperature, and moisture effects on apothecium production of Sclerotinia sclerotiorum. Plant Disease, St. Paul, v.84, n.12, p.1287-1293, 2000.

30. Tomerlin, J.R.; Jones, A.L. Effect of temperature and relative humidity on the latent period of Venturia inaequalis in apple leaves. Phytopathology, St. Paul, v.73, n.1, p.51-54, 1983.

31. Trudgill, D.L. Thermal time - concepts and utility. Annals of Applied Biology, London, v.146, n.1, p.1-14, 2005.

32. Villa Nova, N.A.; Tonato, F.; Pedreira, C.G.S.; Medeiros, H.R. Alternate method to compute the base temperature of forage grasses. Ciência Rural, Santa Maria, v.37, n.2, p.545-549, 2007.

33. Yorinori, J.T.; Paiva, W.M.; Frederick, R.D.; Costamilan, L.M.; Bertagnolli, P.F.; Hartman, G.E.; Godoy, C.V.; Nunes Junior, J. Epidemics of soybean rust (Phakopsora pachyrhizi) in Brazil and Paraguay from 2001 to 2003. Plant Disease, St. Paul, v.89, n.6, p.675-677, 2005.

34. Zadoks, J.C.; Schein, R.D. Epidemiology and Plant Disease Management New York. Oxford University Press, 1979. 427p

35. Zearfoss, A.D.; Cowger, C.; Ojiambo, P.S. A degree-day model for the latent period of Stagonospora nodorum blotch in winter wheat. Plant Disease, St. Paul, v.95 n.5, p.561-567, 2011. 